\title{
Two tales of one city: data, inference and Carthaginian infant sacrifice
}

\author{
J.H. Schwartz ${ }^{1,2, *}$, F.D. Houghton ${ }^{1}$, L. Bondioli ${ }^{3} \&$ R. Macchiarelli ${ }^{4,5}$
}

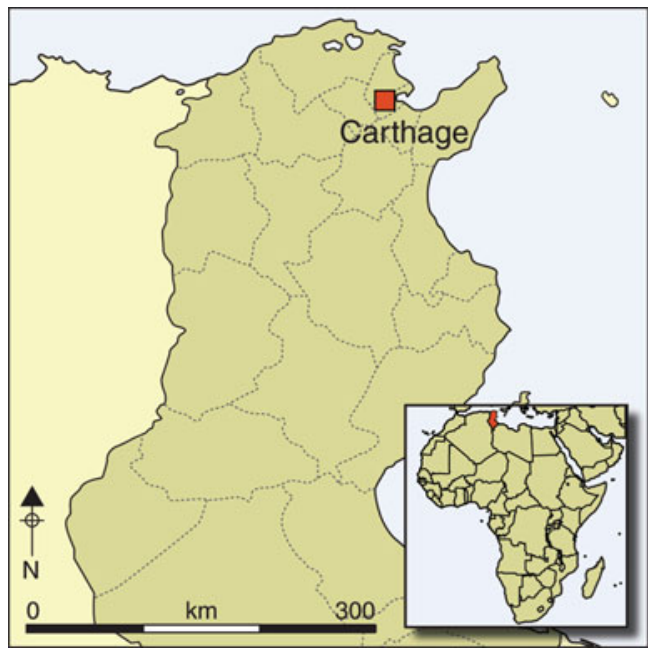

Recent issues of Antiquity have seen much discussion on the topic of Carthaginian infant sacrifice: was it a Graeco-Roman fiction or did it really happen? There are strongly held opinions on both sides of the argument, with much resting on the age profile of the children interred at the cemetery known as the Carthage Tophet. Here, the authors respond to claims by Smith et al. $(2011,2013)$ that their ageing of the infants and children was incorrect, and so also by extension was their interpretation that not all interments at the Tophet were the result of sacrifice.

Keywords: Carthage, Tophet, sacrifice, cremation, osteological analysis

\section{Introduction}

In his second major work, Salammbô, Flaubert (1862) portrayed the Carthaginians as a heartless people who sacrificed their children to gain favour with their gods Tanit and Ba'al Hammon. In this fictional account, a priest places these innocents - tied hand and foot, and cloaked to mask the horror ahead-first individually, and then en masse, in the hands of a huge brass statue of $\mathrm{Ba}$ 'al, whose arms are then raised until the bodies fall into a pyre between its legs. Throughout, musicians play loudly to smother the wails of the victims.

1 Department of Anthropology, University of Pittsburgh, 3302 Wesley W. Posvar Hall, Pittsburgh, PA 15260, USA

2 Department of History and Philosophy of Science, University of Pittsburgh, 1017 Cathedral of Learning, 4200 Fifth Avenue, Pittsburgh, PA 15260, USA

3 Sezione di Antropologia Bioarchaeologia, Museo Nazionale Preistorico Etnografico 'L. Pigorini', Roma, Italia

4 Département de Préhistoire, UMR 7194 Centre National de la Recherche Scientifique (CNRS), Muséum national d'Histoire naturelle, 57 rue Cuvier, 75005 Paris, France

5 Département de Géosciences, Université de Poitiers, 9 rue Charles-Claude Chenou, TSA 51106, 86073 Poitiers Cedex 9, France

* Author for correspondence (Email: jhs@pitt.edu) 
Flaubert's critics chastised him for embracing Graeco-Roman tales of rampant Carthaginian infant sacrifice too literally (Gras et al. 1991).

Flaubert's scenario preceded, by 59 years, the first interpretation of urns bearing the burnt remains of humans and animals from a distinct cemetery (the 'Tophet') at the Carthaginian city of Motya (Motzia), Sicily, as evidence of sacrifice (Whitaker 1921), which Poinssot (Poinssot \& Lantier 1923) then applied to the Carthage Tophet.

Prominent French scholars rejected Whitaker's claim, which they saw as derivative of Flaubert and his reliance on what they considered to be inaccurate Graeco-Roman descriptions of Carthaginian infant sacrifice (Gras et al. 1991). As Saumange wrote in 1922 (translated and quoted in Gras et al. 1991: 151):

The imagination of the public, haunted by Flaubert's memory, has promptly dramatized the discovery: these children [...] are the victims of cruel holocausts which Carthage offered to Moloch. This is an imprudent and grave step to take lightly. Imprudent because it is important to know the excavation perfectly and in all details before advancing such a thing even hypothetically. Grave because one compromises the rehabilitation which the religious reputation of Carthage has benefited from among a good number of our best historians.

May we be permitted to ask ourselves whether the object of the wish was not simply to erect the image of the [...] god himself, and whether the presence of ashes of children could not have been intended to render the place of the betyl [sacred stone] forever untouchable, by burying bones.

In the end, however, Poinssot and Lantier (1923) succeeded in suppressing interpretations of Tophets that argued against sacrifice as the sole cause for the presence of human remains in the Carthage Tophet and others.

Although an 'all-sacrifice' conception of Tophets was not universally accepted (Harden 1927; Soliel et al. 1958; Richard 1961), this interpretation has garnered a following that seeks support from several sources: Graeco-Roman tales by Diodorus and others; the reinterpretation of grave-marker inscriptions as parental vows to sacrifice their offspring to Ba'al and Tanit; the argument that animals were sacrificed and therefore humans were too; the interpretation of images on a particular stele as representing a priest carrying a sacrificial infant; and claims that only sacrifice warranted the use of scarce plant resources for pyres (see references in Smith et al. 2011, 2013; also Xella 2010; Quinn 2011; Xella et al. 2013; Stager 2014).

There is also significant support for a 'not-all-sacrifice' hypothesis, which does not rule out sacrifice, but takes into consideration other factors (see references in Schwartz et al. 2010, 2012): Tophets lie outside city limits and house the remains of prenatal, neonatal and young postnatal humans, which are absent from the main cemeteries in city centres; only Tophet burials are cremations; and the age range of humans buried at Tophets is consistent with natural causes of death. As for the 'seminal' stele (see Smith et al. 2011: fig. 1d), the fully outlined, erect adult figure (with ear, open eye, upright shoulders, upraised right arm with forward-facing hand, distinct manual digits and a bent right leg, well forward of the left leg) contrasts with the minimally outlined small individual that it holds (with down-turned, featureless head, torso, slumped shoulder and a curved line hinting at a limp, handless left 


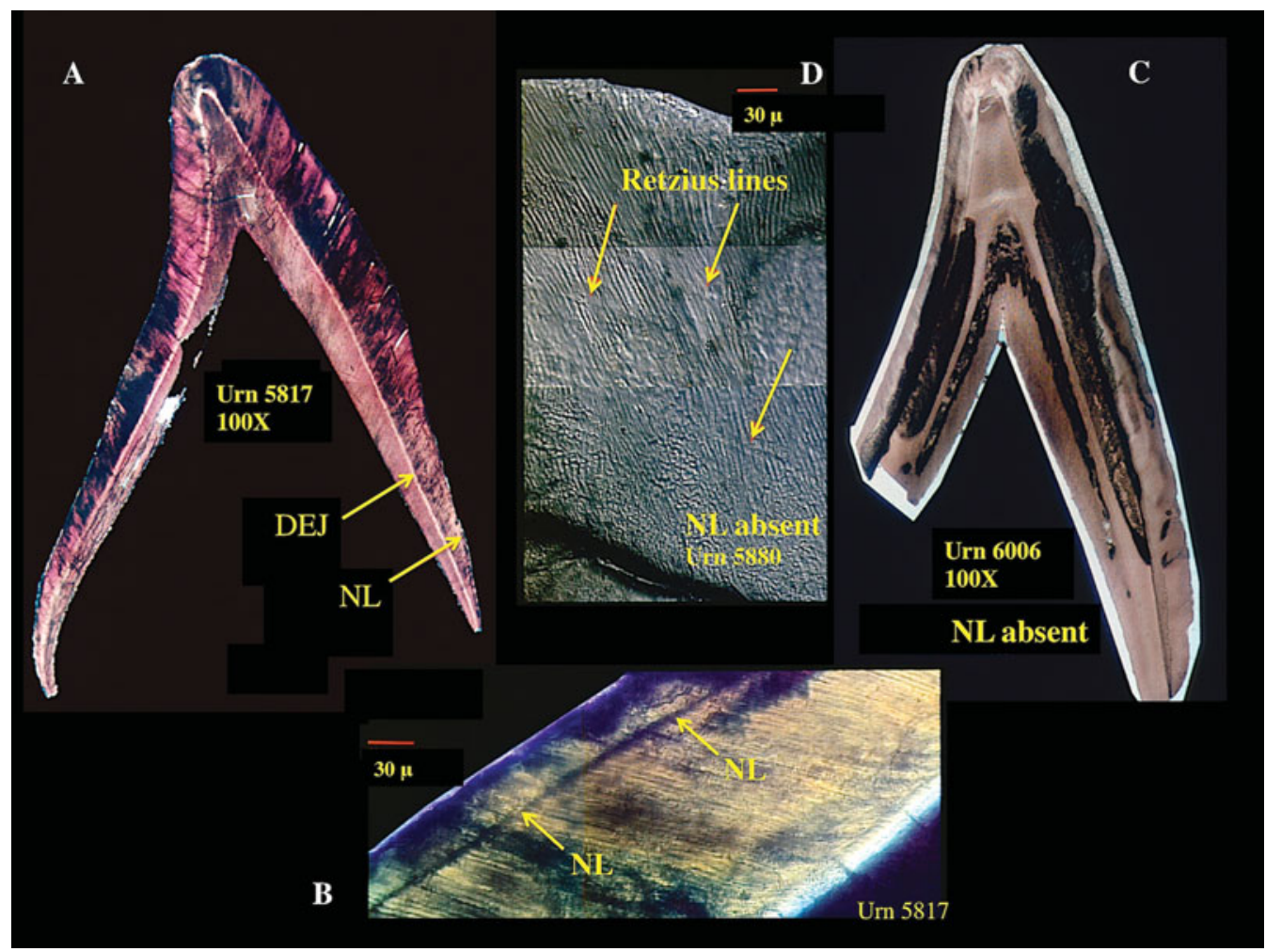

Figure 1. Presence vs absence of neonatal lines in deciduous incisors from the Carthage Tophet. A) At 100 $\times$, the dentinoenamel juncture is more visible than the neonatal line, which is clearly identifiable at $30 \mu(B) . C \& D)$ Neonatal line absent; $D$ illustrates the uninterrupted field of Retzius lines (incremental growth lines in the enamel). Note the level of magnification required to visualise these structures.

arm). Observed without preconception, the adult holds an inanimate (deceased, perhaps cloaked) infant.

Nevertheless, proponents of an 'all-sacrifice' interpretation reject any alternatives, reiterating that Graeco-Roman depictions of specific events actually reflect a widespread Carthaginian practice; that their interpretations of the stele are correct; and that the presence at other Tophets of the cremated remains of humans who 'must' have been sacrificed also means that the Carthage Tophet humans were sacrificed (Smith et al. 2011, 2013; also Xella 2010; Quinn 2011; Xella et al. 2013; Stager 2014). Furthermore, they denounce alternative theories as 'revisionist' (Lancel 1995; Quinn 2011; Stager 2014).

\section{Prior osteological analyses of Carthage Tophet urn contents}

In 1922 and then 1923, Graeco-Roman accounts of infant sacrifice at Carthage seemed validated when de Prorok and colleagues, and Poinssot and Lantier, respectively, discovered urns at the Carthage Tophet containing burnt bones, most of which were identified as belonging to human infants or children (Stager \& Wolff 1984).

(C) Antiquity Publications Ltd, 2017 
Although Kelsey (1926) assumed that most of the Carthage Tophet urns he excavated (more than 1000) contained human remains, neither he nor his successor Harden (1927) claimed that the Carthaginians engaged in rampant, sanctioned infant sacrifice. Between 1934 and 1936, Chabot and Lapeyre unearthed more than 1000 urns at the Tophet, most of which they assumed to contain the remains of either one or two human infants and/or children, or a young human and some animal remains (Lapeyre \& Pellegrin 1942).

After Charles-Picard and Cintas (Charles-Picard 1945) excavated the Carthage Tophet, they gave forensic expert Richard (1961) the contents of 42 urns. Upon combining these remains with those from 138 urns from the Hadrumentum Tophet, Richard identified one or more humans in 88 urns, human and lamb in 59, and lamb in 29.

\section{What the bones tell us}

In 1976, L.E. Stager, director of the team excavating the Tophet, invited one of the authors here (Schwartz) to oversee both the on-site processing and preliminary assessment, and the subsequent detailed laboratory analysis, of the contents of 348 urns from the Carthage Tophet (dated to around the early eighth century to 146 BC) (Schwartz 1993). Using the accepted MNI approach (minimum number of individuals as reflected in the number of the same tooth or skeletal element; Hesse \& Wapnish 1985), Schwartz and Houghton documented evidence of 540 humans. Yet only urns with a MNI of one or two housed sufficient skeletal material to conclude that entire individuals were represented (Schwartz et al. 2010). When an urn's MNI indicated three or more individuals, there was insufficient skeletal material to argue for that number of entire individuals (e.g. there could be three incompletely represented individuals, or one or two skeletally well-represented individuals and only a few elements from other individuals).

As no single criterion can accurately assess age at death-nor in determining sex (Schwartz 2007) — Schwartz and Houghton used the standard multifactorial (multimorphological/metric) approach (Fazekas \& Kósa 1979; Lovejoy et al. 1985; Schwartz 2007). Specifically, we (Schwartz et al. 2010) based estimates of age at death on: the state of crown and root formation (teeth being the most frequently preserved and analysable elements); age-related changes in basisphenoids and petrosals; and measurements of petrosals, lateral occipital parts, basiocciputs, pubes and ischia, which shrink minimally, if at all, when cremated (Krogman 1949). Through numerous re-analyses, we refined the percentages of individuals in each age category.

From accepted age-estimation criteria using tooth and cranial-bone formation, we concluded that pre-/peri-/neonates together constituted $\geq 50 \%$ of the sample (Schwartz et al. 2010). Ages based on basicranial- and pelvic-bone measurements were determined by comparison with Fazekas and Kósa's (1979) measurements of these bones in individuals of known age. We sought to avoid the criticism that cremated bones may have shrunk by incrementally increasing each linear measurement to allow for the possibility of $25 \%$ shrinkage, well beyond the shrinkage recorded for experimentally cremated human or animal remains (see references in Schwartz et al. 2010). Even at 25\% shrinkage, each measurement classified some number of individuals as 'prenatal'.

(C) Antiquity Publications Ltd, 2017 
From these ageing criteria, we concluded that $24 \%$ were prenatal, $15 \%$ peri-/neonatal, and $17 \%$ less than 1 month of age. We tested these results via neonatal line (NL) analysis.

Identifiable in enamel only at high magnification (microns), a NL presents as a distinct, morphologically homogeneous line devoid of cross striations (Figure 1). It reflects a stressinduced disruption of enamel deposition coincident with the transition from in- to exutero, which may not correspond to full-term birth. NLs are always present in deciduous teeth (Antoine et al. 2009), which begin developing by the twentieth intrauterine week (Antoine et al. 2009; also Ten Cate 1989). Since first permanent molar crowns (lower $\mathrm{M}_{1}$ or upper $\mathrm{M}^{1}$ ) mineralise late in the third trimester, their NLs lie closer to the dentinoenamel juncture (DEJ) (Antoine et al. 2009). Given the periodicity of enamel deposition and the lag between a stress and a response to it, an individual must survive around 7 , or even 10-15, post-uterine days for a NL to form (Schwartz et al. 2010).

For NL analysis, Schwartz and Houghton sent co-authors Bondioli and Macchiarelli 50 deciduous tooth crowns from the 'perinatal' category (Schwartz et al. 2010). Twenty-six crowns lacked a NL. In the 24 crowns with NLs, enamel thickness indicated survival of at least two weeks post-NL-formation. Upon comparing NL with our morphological/metrical age estimates $(\mathrm{M})$ of the same individuals, $\mathrm{M}>\mathrm{NL}$ in only $10 \%$ of the sample. As $\mathrm{M}$ typically equalled or over-estimated NL-derived ages, we concluded that M-based age estimates were reliable (Schwartz et al. 2010). Taking everything into account, we concluded that: "the Carthaginian Tophet, and by extension other Tophets, were cemeteries for the remains of human prenates and infants who died from a variety of causes" (Schwartz et al. 2010: 10).

When our analyses consistently identified pre- and neonates, Stager demanded return of the sample, which he sent to P. Smith (Stager 2014). Subsequently, Smith, Stager and others have since dismissed our work through misrepresentation of it, and have also rejected our results and defended the 'all-sacrifice' theory through erroneous assumption and incorrect criteria. Given that these allegations and misinformation appeared in this journal, we present the reader with the relevant background, arguments and correct analytical information.

\section{A refutation?}

Smith et al. (2011: 860-61) not only mischaracterised us (Schwartz et al. 2010) as asserting that the Carthage Tophet was solely "a cemetery for the burial of aborted or stillborn infants", but also criticised us for not accounting for tooth-crown and bone shrinkage, for estimating age primarily on the basis of an inappropriate combination of petrosal length and width measurements, and for using questionable long-bone measurements and NL analysis to estimate age. They also dismissed our analysis because the percentages of identified pre-/perinates were not the same in all cranial and pelvic-bone metric analyses. As most bioarchaeologists know, however, multiple criteria will not yield exactly the same estimate, but, together, they provide a more realistic approximation of age than using one criterion. Smith et al. (2013) subsequently reiterated these objections and defended their age estimates based on tooth-crown height corrected for purported shrinkage, which identified most individuals as one to two postnatal months of age. From this, they asserted that the (C) Antiquity Publications Ltd, 2017 
Carthage humans were alive and available for sacrifice. We address these and other 'bones of contention' individually.

\section{Only sacrifice can account for individuals in the Carthage Tophet}

Regardless of whether some Carthage Tophet humans were sacrificed, it does not preclude death by natural causes (Schwartz et al. 2012): for example, spontaneous abortion, which is common enough today for perinatologists to refer to it as 'reproductive wastage' (Durfee 1987). Furthermore, if we accept that sanitary conditions at Carthage were as poor as at contemporaneous Pompeii, Ostia and Rome (Scobie 1986), all Carthaginians (pregnant women included) were susceptible to cholera, dysentery, gastroenteritis, infectious hepatitis, leptospirosis, typhoid and parasitic intestinal infestations, most of which result in severe dehydration, which remains a primary cause of peri- and postnatal death (Behrman \& Shiono 1997). Also relevant to considering infant mortality are: low birth weight (Behrman \& Shiono 1997); severe viral infections and malaria leading to premature birth and perinatal mortality; infectious diseases (smallpox, vaccinia, listeriosis) resulting in stillbirth; and non-infectious diseases (cholestasis, hypertension, toxemia, renal disease) causing stillbirth, abortion and preterm delivery (Taylor \& Pernoll 1987). As these are today major causes of peri- and postnatal death, they must have constituted natural-and probably more prevalent-elements of Carthaginian life. As Becker (2011: 24) commented in light of the high incidence of perinatal mortality in non-industrial societies and its unexpected increase in modern industrialised societies: "The last months of a pregnancy, the process of parturition, and various stresses during the months after birth provide a frightening trio of challenges that lead to [...] 'infant mortality".

\section{Bone shrinkage}

Our age estimates (pace Smith et al. 2013) did not derive primarily from measurement of the petrosal bone and an inappropriate combination of its length and width. We did measure the petrosal, but we also measured other cranial and several pelvic bones, and compared each measurement individually to those in Fazekas and Kósa's (1979) ageing tables. Moreover, even though these bones shrank little, if at all, when we incrementally increased our measurements to compensate for an unrealistic shrinkage of $25 \%$, prenates were still identified. We did not measure long bones.

\section{Tooth-crown shrinkage}

Even if cremated teeth shrink, their morphology and relative states of development do not change - a fact that others have used when comparing Carthage Tophet crowns with unburned crowns (e.g. Smith et al. 2011, 2013; Figure 2B). Thus, the estimates we achieved using relative states of crown formation are viable (Schwartz et al. 2010).

Although Smith et al. (2013) cited Krogman (1949) as demonstrating marked heat-induced shrinkage, he actually questioned whether this occurred, as unerupted, jaw-embedded developing teeth (as most of the Carthage Tophet teeth were) are less 
A

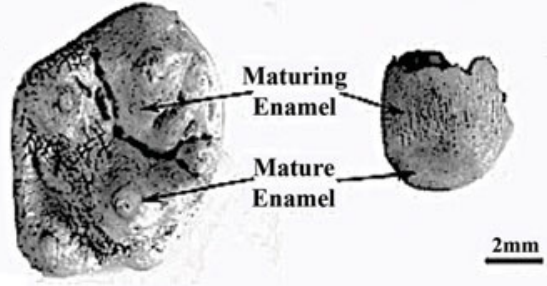

C

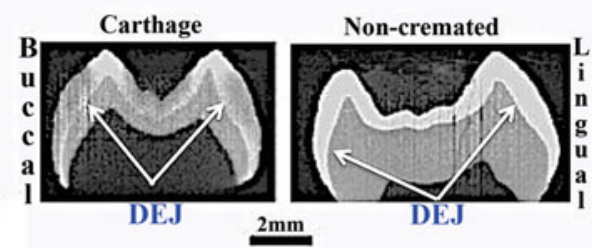

B

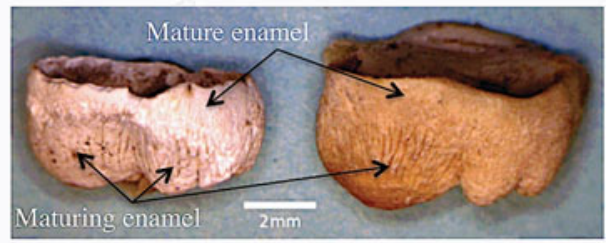

D

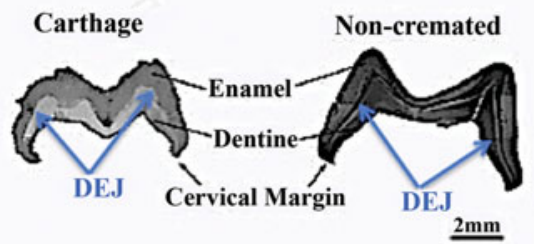

Figure 2. Shrinkage and neonatal lines. A) Developing teeth from the Carthage Tophet illustrating unaltered crown shape via continuity between mature (smooth) and maturing (uneven, due to loss of carbonate and water, not shrinkage) enamel. B) A Carthage Tophet molar (left) and an uncremated molar (right), which Smith et al. (2013) correctly identified as being at the same developmental age, thereby demonstrating that heat does not affect tooth morphology or relative states of development; note continuity of mature and maturing enamel on both specimens. C) Dentino-enamel junctures of Carthage Tophet and uncremated molars; Smith et al. misinterpreted the difference in dentino-enamel juncture clarity as indicating heat-induced elimination of the neonatal line. D) The dentino-enamel junctures of Carthage Tophet molars and uncremated molars; the dark band delineates the dentino-enamel juncture, which Smith et al. (2011) misidentified as a neonatal line. The $2 \mathrm{~mm}$ scale Smith et al. used is insufficient to demonstrate neonatal line presencelabsence. $A, C \& D$ are from Smith et al. (2011); B is from Smith et al. (2013). Black and white (B) and blue and white labelling $(C, D)$ added by present authors.

susceptible to the effects of heat than erupted teeth, which crack and/or split (see also Krogman 1962). They also claimed (Smith et al. 2011, 2013) that both Shipman et al. (1984) and Buikstra and Swegle (1989) demonstrated heat-induced crown shrinkage. Only Shipman and colleagues cremated teeth experimentally, however, and these were erupted sheep molars, which differ from enamel-capped human teeth in having vertical plates of enamel separated by occlusally exposed fields of soft dentine. Not unexpectedly, it was not the crystalline enamel but the hydrated dentine that shrank.

Smith et al. (2011) compared crown heights of specimens from the Carthage Tophet with similarly formed, unburned teeth from an unidentified sample. As the Carthage crowns were $0.6 \mathrm{~mm}$ shorter, they increased their age estimates by around four weeks. Human populations differ markedly in their tooth dimensions (Coughlin 1967; Yuen et al. 1997; Hanihara \& Ishida 2005; Anfe et al. 2012), however, so any effect that heat might have on tooth size can be determined only by measuring the same teeth, pre- and post-cremation, as Deutsch and colleagues (Deutsch \& Shapira 1987; Mayer et al. 1990; Sydney-Zax et al. 1991) and Soliel et al. (1958) did. These studies revealed that shrinkage is at best negligible - a fact that Soliel et al. used to identify pre- and perinates in their Carthage Tophet sample. As for Deutsch et al.'s studies, crown weight decreased as a result of loss of water and carbonates (see Figure 2A \& B). (See also Smith et al. 2013 for incorrectly comparing measurements of cremated teeth from some, with uncremated teeth from other, studies as demonstration of shrinkage.)

(C) Antiquity Publications Ltd, 2017 
Correcting for their inflation of ages, it is striking that Smith and colleagues' mortality distribution is virtually identical to ours when 'fetal' and 'perinatal' categories are combined (Figure S1 in online supplementary material (OSM)). This is consistent with presentday fetal/infant mortality profiles (Chalmers \& Macfarlane 1980; Taylor \& Pernoll 1987; Saunders \& Barrans 1999): in other words, a large proportion of spontaneously aborted or stillborn fetuses (Durfee 1987), and of peri- and neonates, who are at serious risk of death during the first two postnatal weeks (Chalmers \& Macfarlane 1980) (also see our NL estimates above).

\section{Neonatal lines}

Smith et al. $(2011,2013)$ claimed that heat can alter the internal structure of teeth and eliminate evidence of NLs. They also claimed that NLs may be present in permanent, but not deciduous, teeth. From these assertions, they concluded that age estimates based on NL presence/absence are unreliable.

The magnifications used by Smith et al. are insufficient to identify NLs: i.e. millimetres rather than microns $(1 \mu=0.001 \mathrm{~mm})$. Consider their case for asserting that a NL can be present in uncremated, and absent in cremated, teeth. In their fig. $3 \mathrm{~d}$ and $3 \mathrm{e}$, they present a sectioned, uncremated $\mathrm{M}^{1}$ that purports to show a NL and a Carthage Tophet $\mathrm{M}^{1}$ that supposedly lacks this feature (see Figure 2C \& D here). In all cases, however, Smith et al. illustrate the always-present DEJ, which can be identified at low magnification. In Figure $2 \mathrm{C}$, the DEJ is better defined in the uncremated $\mathrm{M}^{1}$ than in the Carthage Tophet $\mathrm{M}^{1}$. In Figure 2D, the DEJ of the Carthage Tophet $\mathrm{M}^{1}$ appears as expected (as it also does in the specimens in Figure 2C), while in the uncremated tooth, separation of dentine and enamel created a dark band that Smith et al. incorrectly identified as a NL. To reiterate: NLs develop not between enamel and dentine, but in enamel, and cannot be visualised in magnifications as low as millimetres.

In support of their contention that deciduous teeth may lack NLs, Smith and colleagues (2013: 1195) cite Antoine et al. (2009) as being able to "locate this line in only one of five teeth they examined". Antoine et al. (2009: 49) actually wrote that NLs can always be identified in deciduous crowns, which begin to form months before birth, but may be difficult to locate in the less fully developed M1 crowns of pre-, peri- and neonates because they lie close to the DEJ. This accounts for their being able to identify a NL in only one of the five permanent molars that they analysed (a $M_{1}$ vs $3 M_{1}$ s and $1 \mathrm{M}^{1}$ ). As we only scrutinised deciduous teeth for NLs, we stand by our results-26 of 50 crowns lacked a $\mathrm{NL}$ - which confirms the presence of some number of prenates.

\section{Do other studies support the 'all-sacrifice' theory?}

Richard (1961) analysed the contents of 42 urns from the Carthage Tophet together with remains from 138 urns from the Hadrumentum Tophet. From long-bone measurements representing 41 individuals, he identified $5(12.2 \%)$ prenates (1 of 7.5 fetal months, and 4 of 8-9 fetal months), $20(48.8 \%)$ perinates, and $16(39 \%)$ postnates ( 9 of $\leq 1$ month, 3 of $1-3$ months, and 4 of 2-3 years). Conservatively, he suggested 1 prenate, 33 perinates and 7 postnates. Using developing teeth representing 147 humans, Richard 
identified 16 prenates $(10.9 \%), 118$ perinates $(80.3 \%)$ and 13 postnates $(8.8 \%$; 6 of a few months of age, 7 of 3-6 years). His conservative estimate was 13 postnates, from 2-16 prenates, and the rest as perinates. Recognising that his results were consistent with expected mortality, Richard tentatively suggested that 5\% were prenatal, $75 \%$ perinatal and 20\% postnatal (pace Smith et al. 2011, 2013). As 26 teeth that we classified as 'perinatal' lacked a NL, Richard's perinatal category probably included prenates.

Based on a small number of bones from 16 Carthage Tophet urns, Gejvall (1949) suggested that 1 human was neonatal to 3 months of age, 7 were greater than 3 months, and 3 were 3-4 postnatal months. Given Gejvall's small sample, his conclusions are not inconsistent with ours (pace Smith et al. 2011, 2013).

Additionally, Muller et al. (1952) analysed the contents of 44 Carthage Tophet urns and those of 31 urns from the Sousse Tophet. They identified humans in 32 urns, animals in 2 urns and commingled human/animal remains in 38 urns. They determined age using sphenoid development/coalescence, long-bone length, Haversian canal configuration and semicircular canal orientation: 65 individuals (around $87 \%$ of the sample) were near birth, 1 of 21 days, 2 of 30 postnatal days, and the rest of 2-3 postnatal months. Some of the 65 individuals were probably prenatal.

Recently, Xella (2009) defended the 'all-sacrifice' theory via his 'new' approach, which relied solely on classical Greek and Roman writings. Subsequently, Xella and colleagues (Xella 2010; Quinn 2011; Xella et al. 2013) included the interpretations of archaeologists, historians and epigraphers, which, they concluded, tell the same story: Tophets were cemeteries for sacrificed children. Smith et al.'s claims fit their interpretation. They (Xella et al. 2013) rejected our results on the grounds that analyses by Docter et al. (2003), Melchiorri (2010) and Ciasca et al. (1996) contradicted ours.

Docter et al. studied 6 Carthage Tophet urns. Using tooth and skeletal development, they identified 3 newborns in 1 urn, 2 newborns in each of 2 urns, 1 newborn in each of 2 urns, and one 6-9-year-old child in $1 \mathrm{urn}$. Given our results, it is probable that 3 complete individuals were not represented in that first urn, and that 'newborn' includes prenates.

Melchiorri analysed 72 Sulci Tophet (Sardinia) urns, and identified 52 humans, ranging in age from prenatal to $4-5$ years. Of the 30 classified as neonatal, some were probably prenatal.

From the Motya Tophet, Ciasca et al. (1996) identified human remains in 132 urns, and comingled human and animal remains in 303 urns. They reported that the humans ranged in age from birth (the majority) to 6 months. For 112 of these individuals, they determined that $95(84.8 \%)$ were neonates, 8 were 1 month of age, 4 were 2 months, 1 was 2-3 months, 3 were 4 months, and 1 was 6 months of age. 'Neontatal' undoubtedly included prenates.

\section{Animal remains}

Another defence of the 'all-sacrifice' theory is that as all Carthage Tophet animals must have been sacrificed, all humans must also have been sacrificed (see references in Smith et al. 2011, 2013; see also Xella 2010; Xella et al. 2013).

(C) Antiquity Publications Ltd, 2017 
We identified lamb or kid alone in some urns, and lamb or kid, and infrequently bird and fish, commingled with human bones in others (Schwartz et al. 2010). Never, however, was there enough bone to suggest the interment of an entire animal (see Table S1 in OSM). This pattern is consistent with then contemporaneous practice: although an animal may have been killed sacrificially, only part of it (that was less desirable for eating) was burned as an offering to the gods; the rest was consumed (Detienne 1989). Given the skewed representation of animal skeletal elements, it appears that the circumstances leading to their presence in the Carthage Tophet differed from those involving humans.

Advocates of the 'all-sacrifice' theory also specify when this event occurred. Gejvall (1949) and Docter et al. (2003) thought that all lamb/kid remains from the Carthage Tophet represented spring-born neonates, and Stager (2014) extrapolated from this, and from the rare occurrence of commingled bird and human remains, to the notion of a regular springtime ritual. Our data, however, demonstrate that the low incidence of lamb/kid/bird remains, whether alone, or commingled with human bones (Table S1), cannot support the claim: if all humans were sacrificed, it was always in the spring. More broadly, given the number of potential natural causes of death (see above), it is unlikely that Carthaginians, whether or not interred in the Tophet, died only at certain times of the year.

\section{Yet another justification of the 'all-sacrifice' theory?}

As deforestation began with the founding of Carthage (van Zeist et al. 2001), it has been argued that nothing less profound than sacrificial cremation would warrant the use of dwindling wood resources otherwise needed for building ships and habitation (Smith et al. $2011,2013)$. In reality, Carthage Tophet pyres typically comprised thin branches (Schwartz 1993; Docter et al. 2003), mostly from cultivated small trees (e.g. Prunus) and bushes (e.g. Ligustrum) (Docter et al. 2003). Furthermore, charcoal of the largest plant present (Quercus) suggests that only scraps - probably left over from large-scale construction-were used (Docter et al. 2003).

\section{Conclusion}

In summary, Tophets housed the remains of primarily pre-/perinates, newborns and children $\leq 5$ years of age, and lay outside the city, while main cemeteries lay within city limits and typically contained humans $\geq 5$ years. Only Tophet individuals were cremated and interred in urns. The disparity between urns in the presence of entire individuals, as well as often marked differences between urn contents in degree of incineration (including skeletal elements still in articulation), probably reflects differences at different times and on different occasions in acts of cremation and efforts to recover remains (Schwartz et al. 2010). Furthermore, cloth adhering to the internal side of a perinate's barely burned ilium suggests that, after cooling, bones were collected and either wrapped or placed in sacks before being placed in an urn (Schwartz 1993; Figure S2 in OSM).

That Carthaginians maintained two different cemeteries is compatible with the Punicderived, Roman-Carthaginian practice of not considering offspring as 'persons' until they had survived a certain number of years (Norman 2002; Stuckey 2009). Furthermore, as Becker (2011) reviews in detail from study of Cazzanello and other south Etrurian sites 
(e.g. Tarquinia), the burial of prenates, perinates and even children up to five years of age in cemeteries apart from the main cemetery was apparently commonplace in Etruscan culture.

From this perspective, rather than conceiving of the Carthage Tophet as a sanctuary solely for the sacrificed, it is not unreasonable to perceive it as a cemetery for humans (with or without attendant animal sacrifices) who, having died prior to formal acceptance into society, were returned to the gods through the smoke of cremation (Stuckey 2009). Moreover, given that the Carthage Tophet and Cazzanello's children's cemetery are similar in both housing perinates and children, but only Carthage Tophet individuals were cremated, the difference between these two cemeteries is reasonably attributed to cultural differences in burial, not sacrificial, practice (cf. Becker 2011).

While Xella (2009, 2010; Xella et al. 2013) and others (e.g. Quinn (2011) defend the 'all-sacrifice' theory by giving priority to non-osteological sources- "archaeology, historical and especially epigraphic evidence” (Xella et al. 2013: 1206) — none can falsify osteological evidence: the teeth and bones of a prenate are the teeth and bones of a prenate. As Becker (2011:31) cautioned in considering infant $v$ s main cemeteries in Rome and Etruria: "Direct evidence suggest $[s \ldots]$ that historians and others might wish to consider how the biological evidence relates to their interpretations of the written records".

Although questions remain regarding the reality and extent of Carthaginian infant sacrifice, as well as the identity of those who buried their offspring in Tophets (probably not the poor who, unable to afford formal burial, would seek other avenues for disposing of the dead; cf. Becker 2011), it seems prudent to think beyond the bizarre and inhumane, and to consider all potential aspects of daily life, in which the unspectacular and mundane are also important: Tophets were cemeteries for the very young, regardless of how they died.

\section{Acknowledgements}

Thanks to Bruno Maresca and Amélie Vialet for help in translation, and to Marshall Becker and Thomas Plummer for supporting our endeavour.

\section{Supplementary material}

To view supplementary material for this article, please visit https://doi.org/10.15184/aqy. 2016.270

\section{References}

Anfe, T., Y. Arakaki, D.M. Nakamura \& G.F. Viera. 2012. Mesiodistal and buccolingual crown size of deciduous teeth from a tooth bank in Brazil. Brazil Dental Science 15: 74-78.

Antoine, D., S. Hillson \& M.C. Dean. 2009. The developmental clock of dental enamel: a test for the periodicity of prism cross-striations in modern humans and an evaluation of the most likely sources of error in histological studies of this kind. Journal of Anatomy 214: 45-55. https: //dx.doi.org/10.1111/j.1469-7580.2008.01010.x
BeCKer, M.J. 2011. Etruscan infants: children's cemeteries at Tarquinia, Italy as indicators of an age of transition, in M. Lally \& A. Moore (ed.) (Re)thinking the little ancestor: new perspectives on the archaeology of infancy and childhood: 24-36. Oxford: Archaeopress.

Behrman, R.E. \& P.H. Shiono. 1997. Neonatal risk factors, in A.A. Fanaroff \& R.J. Martin (ed.) Neonatal-perinatal medicine: diseases of the fetus and infant: 3-12. St Louis (MO): Mosby.

Buikstra, J.E. \& M. Swegle. 1989. Bone modification due to burning: experimental evidence, in R. Bonnischen \& M.H. Sorg (ed.) Bone modification: 247-58. Orono: University of Maine. 
Chalmers, J. \& A. Macfarlane. 1980. Interpretation of perinatal statistics, in B.A. Wharton (ed.) Topics in perinatal medicine: $1-11$. Tunbridge Wells: Pitman Medical.

Charles-Picard, G. 1945. Le sanctuaire dit de Tanit à Carthage. Comptes-rendus des séances de l'Academie des Inscriptions et Belles-Lettres 89: 443-52.

Ciasca, A., R. Di Salvo, M. Castellino \& C. Di PAтTi. 1996. Saggio preliminare sugli incinerati del 'tofet' di Mozia. Vicino Oriente 10: 317-46.

Coughlin, J.W. 1967. Sex differences in the prenatal human deciduous molar crown. Jounral of Dental Research 46: 554-58. https://doi.org/10.1177/00220345670460031701

Detienne, M. 1989. Culinary practices and the spirit of sacrifice, in M. Detienne \& J.-P. Vernant (ed.) The cuisine of sacrifice among the Greeks: 1-20. Chicago (IL): University of Chicago Press.

Deutsch, D. \& L. Shapira. 1987. Changes in mineral distribution and conentration during enamel development in the deciduous human maxillary and mandiblar teeth. Growth 51: 334-41.

Docter, R.F., E. Smits, T. Hakbijl, I.L.M. Stuijts \& H. vAN DER Plicht. 2003. Interdisciplinary research on urns from the Carthaginian tophet and their contents. Paleohistoria 43-44(2001-2002): 417-33.

DurfeE, R.B. 1987. Obstetric complications of pregnancy, in B.A. Wharton (ed.) Topics in perinatal medicine: 255-78. Tunbridge Wells: Pitman Medical.

FazeKas, I.G. \& F. Kósa. 1979. Forensic fetal osteology. Budapest: Akademiai Kiado.

Flaubert, G. 1862. Salammbô. Paris: Michel Levy.

Gejvall, N.-G. 1949. Determination of cremated bones from Carthage. Oxford: Ashmolean Museum.

Gras, M., P. Rouillard \& J. Teixidor. 1991. The Phoenicians and death. Berytus_-Archaeological Studies 39: 127-76.

Hanihara, T. \& H. Ishida. 2005. Metric dental variation of major human populations. American Journal of Physical Anthropology 128: 287-98. https://doi.org/10.1002/ajpa.20080

Harden, D. 1927. Punic urns from the Precinct of Tanit at Carthage. American Journal of Archaeology 31: 297-310. https://doi.org/10.2307/497821

Hesse, B. \& P. Wapnish. 1985. Animal bone archaeology: from objectives to analysis. Washington, D.C.: Taraxacum.

Kelsey, F.W. 1926. Excavations at Carthage, 1925: a preliminary report. New York: Macmillan.

Krogman, W.M. 1949. The human skeleton in legal medicine: medical aspects, in S.A. Levinson (ed.) Symposium on medicolegal problems: 1-92. Philadelphia (PA): J.B. Lippincott.
- 1962. The human skeleton in forensic medicine. Springfield (IL): Charles C. Thomas.

Lancel, S. 1995. Carthage: a history. Oxford: Oxford University Press.

Lapeyre, R.P. \& A. Pellegrin. 1942. Carthage Punique (814-146 avant J.-C.). Paris: Payot.

Lovejoy, C.O., R.S. Meindl, R.P. Mensforth \& T.J. Barton. 1985. Multifactorial determination of skeletal age at death: a method and blind tests of its accuracy. American Journal of Physical Anthropology 68: $1-14$. https://doi.org/10.1002/ajpa.1330680102

Mayer, I., S. Schneider, M. Sydney-Zax \& D. Deutsch. 1990. Thermal decomposition of developing enamel. Calcified Tissue International 46: 254-57. https://doi.org/10.1007/BF02555004

Melchiorri, V. 2010. Le Tophet de Sulci (S. Antioco, Sardaigne). État des études et perspectives de la recherche. Ugarit-Forshungen 41(2009): 509-24.

Muller, M., R. Depreux, P. Muller \& M. Fontaine. 1952. Recherches anthropologiques sur les ossements retrouvés dans des urnes puniques. Bulletins et Mémoires de la Société d'Anthropologie de Paris, series $X$ 3: 160-73. https://doi.org/10.3406/bmsap.1952.2909

Norman, N.J. 2002. Death and burial of Roman children: the case of the Yasmina cemetery at Carthage_-part I, setting the stage. Mortality 7: 302-23. https://doi.org/10.1080/1357627021000025469

Poinssot, L. \& R. LANTiER. 1923. Un sanctuaire de Tanit à Carthage. Revue de l'Histoire des Religions 1923: 32-66.

Quinn, J. 2011. The cultures of the Tophet. Identification and identity in the Phoenician diaspora, in E.S. Gruen (ed.) Cultural identity in the ancient Mediterranean: 388-413. Los Angeles (CA): Getty Research Institute.

Richard, J. 1961. Étude médico-légale des urnes sacrificielles puniques et de leur contenu. Unpublished PhD dissertation, Université de Lille.

Saunders, S.R. \& L. Barrans. 1999. What can be done about the infant category in skeletal sample?, in R.D. Hoppa \& C.M. Fitzgerald (ed.) Human growth in the past: studies from bones and teeth: 183-209. Cambridge: Cambridge University Press.

Schwartz, J.H. 1993. What the bones tell us. New York: Henry Holt \& Co.

- 2007. Skeleton keys: an introduction to human skeletal morphology, development, and analysis. New York: Oxford University Press.

Schwartz, J.H., F. Houghton, R. Macchiarelli \& L. Bondioli. 2010. Skeletal remains from Punic Carthage do not support systematic sacrifice of infants. PLoS ONE 5: 1-12. https://doi.org/10.1371/journal.pone.0009177 


\section{J.H. Schwartz et al.}

Schwartz, J.H., F. Houghton, L. Bondioli \& R. Macchiarelli. 2012. Bones, teeth, and estimating age of perinates: Carthaginian infant sacrifice revisited. Antiquity 86: 738-45. https://doi.org/10.1017/S0003598X00047888

Scobie, A. 1986. Slums, sanitation, and mortality in the Roman world. Klio 2: 399-433.

Shipman, P., G. Forster \& M. Schoeninger. 1984. Burnt bones and teeth: an experimental study of colour, morphology, crystal structure and shrinkage. Journal of Archaeological Science 11: 307-25. https://doi.org/10.1016/0305-4403(84)90013-X

Smith, P., G. Avishai, J.A. Greene \& L.E. Stager. 2011. Aging cremated infants: the problem of sacrifice at the Tophet of Carthage. Antiquity 85: 859-75. https://doi.org/10.1017/S0003598X00068368

Smith, P., L.E. Stager, J.A. Greene \& G. Avishai. 2013. Age estimations attest to infant sacrifice at the Carthage Tophet. Antiquity 87: 1191-99. https://doi.org/10.1017/S0003598X00049954

Soliel, J., P. Muller \& J. Richard. 1958. Contribution à la détermination de l'âge des enfants sacrifiés à Carthage (étude des chapeaux de dentine calcinés). Annales de Médecine Légal et de Criminologie 38: 17-25.

Stager, L.E. 2014. Rites of spring in the Carthaginian Tophet. Paper presented at the Babesch Byvanck Lecture, Leiden, The Netherlands, 2014.

Stager, L.E. \& S.R. Wolff. 1984. Child sacrifice at Carthage: religious rite or population control. Biblical Archaeology Review 10: 31-51.

Stuckey, J. 2009. Tanit of Carthage. MatriFocus 8: 1-12. Available at: http://www.matrifocus.com/LAM09/spotlight.htm (accessed 9 December 2016).
Sydney-Zax, M., I. Mayer \& D. Deutsch. 1991 Carbonate content in developing human and bovine enamel. Journal of Dental Research 70: 913-16. https://doi.org/10.1177/00220345910700051001

TaYlor, C.M. \& M.L. Pernoll. 1987. Normal pregnancy \& prenatal care, in M.L. Pernoll \& R.C. Benson (ed.) Current obstetric \& gynecologic diagnosis \& treatment 1987: 161-77. Norwalk (CT): Appleton \& Lange.

Ten Cate, A.R. 1989. Physiological tooth movement: eruption, and shedding, in A.R. Ten Cate (ed.) Oral histology: development, structure, and function: 275-98. St Louis (MO): The C.V. Mosby Company.

van Zeist, W., S. Bottema \& M. van der Veen. 2001. Diet and vegetation at ancient Carthage: the archaeological evidence. Gröningen: Gröningen Institute of Archaeology.

Whitaker, J.I.S. 1921. Motya: a Phoenician colony in Sicily. London: G. Bell \& Sons.

Xella, P. 2009. Sacrifici di bambini nel mondo Fenicio e Punio nelle tesmonianze in linguq Grec e Latina: 1. Studi epigrafici e linguistici sui Vicino Oriente antico 25: 59-100.

- 2010. Per un 'modello interpretativo' del tofet: il tofet come necropoli infantile?, in P. Bartoloni, P. Matthiae, I. Nigro \& L. Romano (ed.) Tiro, Cartagine, Lixus: nuove acquisizioni. Atti del convegno internazionale in onore di Maria Giulia Amadasi Guzzo: 259-79. Roma: Università di Roma 'La Sapienza'.

Xella, P., J. Quinn, V. Melchiorri \& P. van Dommelen. 2013. Phoenician bones of contention. Antiquity 87: 1199-207. https://doi.org/10.1017/S0003598X00049966

Yuen, K.K.W., L.L.Y. So \& E.L.K. TANG. 1997. Mesiodistal crown diameters of the primary and permanent teeth in southern Chinese-a longitudinal study. European Journal of Orthodontics 19: 721-31. https://doi.org/10.1093/ejo/19.6.721

Received: 22 June 2016; Accepted: 3 November 2016; Revised: 19 September 2016

(C) Antiquity Publications Ltd, 2017 